\title{
Corundum-Kyanite Eclogite, Grospydite and Epidote Amphibolite of Probable Subducted Slab Origin from Paleogene Diamondiferous Pipes in SW Wyoming
}

Kuehner, Scott M. and Irving, Anthony J.

Dept. of Geological Sciences, University of Washington, Seattle, WA 98195, USA (kuehner@u.washington.edu)

Widespread eclogitic garnet and chromian diopside grains in antmounds in southwestern Wyoming have a proximal source in the Bishop Conglomerate which caps a regional erosion surface (McCandless and Nash, 1996), but the distal sources appear to be at least ten diatremes and dikes intruding the underlying Bridger Formation on the western end of Cedar Mountain. Several diamonds have been reported in drill core from one of these diatremes (Guardian Enterprises, 1995, 1996, 1997) and a few alluvial diamonds also have been found in the region. We have examined the antmounds, conglomerate and diatremes in order to characterize the variety of lithospheric xenoliths and the agent that transported them from depth. Although located halfway between the OligoceneMiocene lamproites near Francis, Utah and the Plio-Pleistocene lamproites of the Leucite Hills, Wyoming (Mitchell and Bergman, 1991), the Cedar Mountain magmatic phase appears to have neither lamproitic nor kimberlitic affinities. All three localities lie along the southern margin of the Wyoming Craton, yet the xenolith types in the Cedar Mountain pipes suggest that any diamonds might be of shallow subduction origin rather than being derived from a deep cratonic keel.

\section{Geologic Setting and Age}

The Cedar Mountain intrusive bodies appear to be narrow dikes and clast-choked pipes cutting volcaniclastic sandstones, siltstones and shales of the Eocene Bridger Formation. The disconformably overlying Bishop Conglomerate, which contains tuffs dated at $29 \mathrm{Ma}$, caps most of the high mesas in the region around Lonetree (Hansen, 1986; Dover and M'Gonigle, 1993). Thus, the age of emplacement of the pipes probably was between 30 and $40 \mathrm{Ma}$ ago. Whether the pipes ever erupted above the Eo-Oligocene surface is conjectural, but they and their lithospheric xenoliths evidently were exposed to erosion by at least $29 \mathrm{Ma}$ ago, and were re-exposed upon retreat of the capping Bishop Conglomerate perhaps as recently as Pleistocene time. The Bishop Conglomerate represents a high energy, alluvial fan deposit (Hansen, 1986) containing boulder to sand-sized detritus of Paleozoic to Precambrian sedimentary, igneous and metamorphic rocks derived mostly from the Uinta Mountains to the south. In the vicinity of Lonetree the lower conglomerates are commonly cemented by calcite and contain sparse eclogite, epidote amphibolite and other detritus of deep lithospheric origin within a narrow zone $30-90 \mathrm{~cm}$ above the basal contact.

\section{Petrology and Mineralogy of Clasts}

A suite of small lithic and mineral clasts was recovered by acetic acid digestion and handpicking from a large sample of Bishop Conglomerate collected $4.5 \mathrm{~km}$ northeast of the diatremes. Mineral grains were also collected directly from antmounds, and by heavy liquid separation of soil and antmound samples. Most of our characterization of the clasts to date has entailed electron microprobe petrography and EDS analysis of constituent phases. The lithic clast types include bimineralic eclogite, corundum eclogite, corundum-kyanite eclogite, grospydite, garnet-phengite-quartz granulite, and a distinctive suite of epidote-amphibole-rich assemblages containing varying amounts of titanite, rutile, allanite, omphacitic pyroxene, biotite, zircon, and ilmenite with minor barite and celestite. 
One corundum eclogite contains more jadeitic clinopyroxene and more grossular-rich garnet than a bimineralic eclogite (Table 1). Mineral clasts include garnet, chromian diopside, low-Ca augite, bronzite, $\mathrm{Cr}-\mathrm{Al}$ spinel, chromite, ilmenite and pseudobrookite (see Table 1). No olivine has been observed. The cm-sized grains of glassy augite and enstatite (the latter containing abundant oriented chromite needles) do not contact any of the other minerals, suggesting that they may be high temperature megacrysts possibly related to the diatreme magma. Our results for antmound minerals affirm the findings of McCandless and Nash (1996); additional discoveries are one grain each of blue corundum, pink aluminosilicate and anorthoclase. Xenoliths from one Cedar Mountain diatreme include epidote-amphibole-rich rocks (some omphacite-bearing), metabasites composed of blue-green barroisitic amphibole and epidote+albite intergrowths, garnet-phengite-quartz granulite, and a large diopside grain with euhedral phlogopite inclusions. Many of the mineral assemblages in xenoliths and clasts are typical of subduction complexes (e.g., Evans, 1990; Sorensen and Grossman, 1993). The entire suite is explicable by subduction metamorphism of oceanic sediments and variably altered basalts, as described in the Barron et al. (1996) subduction model for diamond genesis.

\section{Magmatic Component of Cedar Mountain Diatremes}

We have examined in detail a sample of light grey, fine grained, clast-laden magmatic breccia from one pipe and a sample of a narrow dike-like apophysis of the same intrusion. In addition to debris from a variety of crustal lithologies, we have identified chromian diopside similar in composition to that from antmounds, but no garnet, corundum or kyanite. The very complex, very fine grained breccia matrix consists of highly silicic, presumably hydrous glass (amorphous by electron diffraction) containing xenocrysts as well as euhedral to subhedral grains of phlogopite, Srapatite, richterite, anorthoclase, sanidine, plagioclase, chromite, pyrite, barite and calcite, but not clinopyroxene. Acicular mica microlites form radiating masses or dense bunches in flow alignment around larger clasts (Figure 1), and appear to have precipitated from the inter-clast fluid. The micas are $\mathrm{Mg}$-rich but unusually low in $\mathrm{Ti}, \mathrm{Na}, \mathrm{Cr}$, and $\mathrm{F}$ (Table 1), and differ from micas in kimberlites, orangeites, lamproites and the sandstones of the Bridger Formation (Figure 2). The richterite has lower $\mathrm{Ti}$ and $\mathrm{K}$ (Table 1) than similar amphiboles in lamproites. Three distinct types of feldspar occur as individual grains and sanidine also forms overgrowths on plagioclase grains; 14 analyses range from $\mathrm{An}_{53} \mathrm{Ab}_{45} \mathrm{Or}_{2}$ through anorthoclase to $\mathrm{An}_{0} \mathrm{Ab}_{1} \mathrm{Or}_{99}$. The matrix appears to represent a disequilibrium quench assemblage from a very low viscosity, hydrous, mafic, alkalic magmatic liquid or fluid, but the exact nature of any deeper, related alkalic magma remains uncertain.

\section{References}

Barron, L. M., Lishmund, S. R., Oakes, G. M., Barron, B. J., and Sutherland, F. L., 1996, Subduction model for the origin of some diamonds in the Phanerozoic of eastern New South Wales: Aust. J. Earth Sci., 43, p. $257-267$.

Dover, J. H. and M'Gonigle, J. W., 1993, Geologic map of the Evanston 30'x60' quadrangle, Uinta and Sweetwater Counties, Wyoming: U.S. Geol. Survey Misc. Inv. Series Map I-2168.

Evans, B. W., 1990, Phase relations of epidote-blueschists: Lithos, 25, p. 3-23.

Guardian Enterprises, 1995, New kimberlite field discovered in the Wyoming Craton: Guardian Enterprises website. Guardian Enterprises, 1996, Diamonds in Wyoming: Ibid.

Guardian Enterprises, 1997, Exploration program underway on Wyoming diamond properties: Ibid.

Hansen, W. R., 1986, Neogene tectonics and geomorphology of the eastern Uinta Mountains in Utah, Colorado and Wyoming: U.S. Geol. Survey Prof. Paper 1356.

McCandless, T. E. and Nash, W. P., 1996, Detrital mantle indicator minerals in southwestern Wyoming, U.S.A.: Evaluation of mantle environment, igneous host, and diamond exploration significance: Expl. Min. Geol., 5, p. 33-44. Mitchell, R. H. and Bergman, S. C., 1991, Petrology of Lamproites: Plenum, New York.

Sorensen, S. S. and Grossman, J. N., 1993, Accessory minerals and subduction zone metasomatism: a geochemical comparison of two mélanges (Washington and California, U.S.A): Chem. Geol., 110, p. 269-297. 


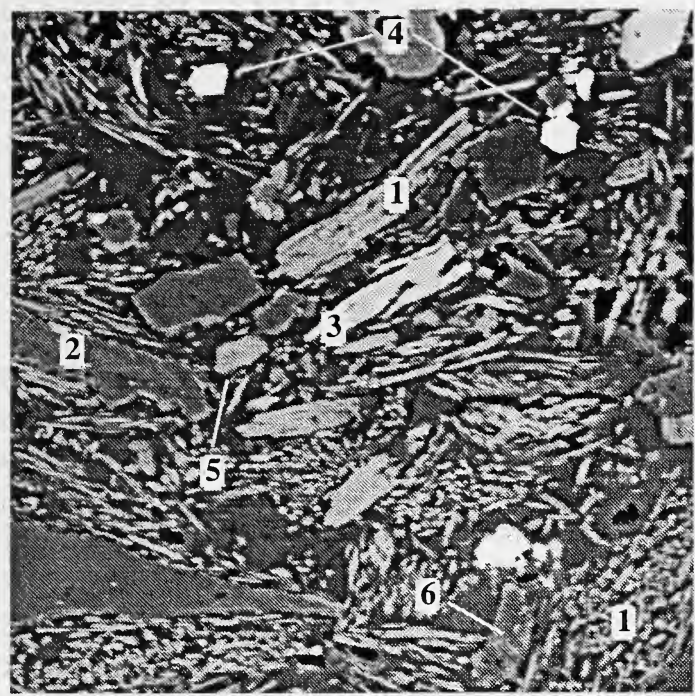

Figure 1. 1) mica; 2) plagioclase $\left(\mathrm{An}_{49} \mathrm{Or}_{2}\right)$ rimmed by $\mathrm{An}_{4} \mathrm{Or}_{21}$ anorthoclase; 3 ) richterite; 4) pyrite;

5) sanidine $\left.\left(\mathrm{Or}_{99}\right) ; 6\right)$ sanidine $\left(\mathrm{An}_{5} \mathrm{Or}_{41}\right)$. BSE image, width $90 \mu \mathrm{m}$.

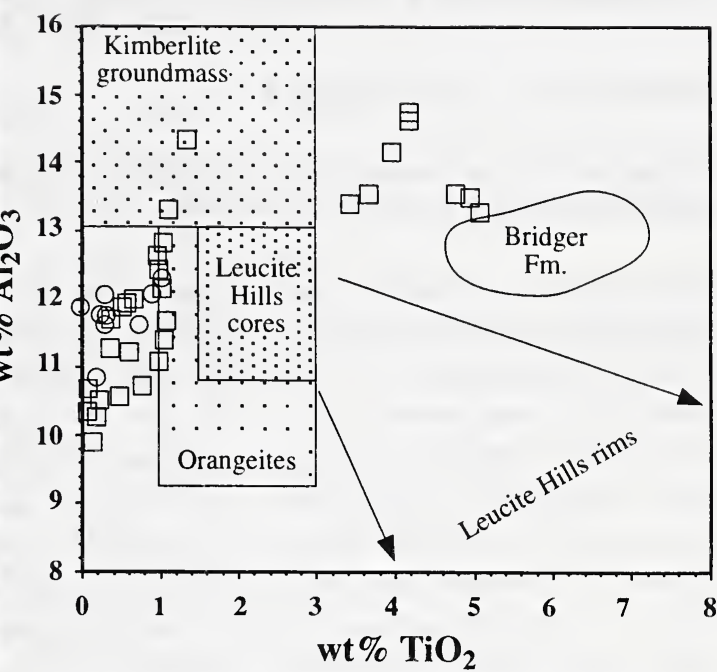

Figure 2. Compositions of mica in Cedar Mountain breccia. Circles- matrix grains. Squares- undifferentiated large grains.

Table 1. Compositions of diatreme matrix phases and clasts from the Bishop Conglomerate

\begin{tabular}{|c|c|c|c|c|c|c|c|c|c|c|c|c|}
\hline $\mathrm{SiO}_{2}$ & $\begin{array}{c}1 \\
57.55\end{array}$ & $\begin{array}{c}2 \\
42.64\end{array}$ & $\begin{array}{c}3 \\
87.74\end{array}$ & $\begin{array}{c}4 \\
43.43\end{array}$ & $\begin{array}{c}5 \\
55.97\end{array}$ & $\begin{array}{c}6 \\
55.60\end{array}$ & $\begin{array}{c}7 \\
55.73\end{array}$ & $\begin{array}{c}8 \\
41.20\end{array}$ & $\begin{array}{c}9 \\
55.88\end{array}$ & $\begin{array}{l}10 \\
0.53\end{array}$ & $\begin{array}{l}11 \\
0.52\end{array}$ & $\begin{array}{c}12 \\
0.47\end{array}$ \\
\hline $\mathrm{TiO}_{2}$ & 0.08 & 1.05 & 0.09 & 0.13 & 0.0 & 0.08 & 0.15 & 0.0 & 0.0 & 0.12 & 0.46 & 34.40 \\
\hline $\mathrm{Al}_{2} \mathrm{O}_{3}$ & 2.02 & 12.30 & 2.58 & 22.95 & 5.42 & 0.45 & 3.48 & 22.70 & 3.80 & 44.34 & 8.39 & 0.48 \\
\hline $\mathrm{Cr}_{2} \mathrm{O}_{3}$ & 0.03 & 0.05 & 0.00 & 0.23 & 0.23 & 0.18 & 0.68 & 0.22 & 0.24 & 21.58 & 42.44 & 2.39 \\
\hline $\mathrm{FeO}$ & 2.68 & 6.90 & 0.54 & 7.09 & 0.93 & 4.46 & 3.53 & 12.71 & 1.26 & 18.01 & 39.76 & 59.72 \\
\hline $\mathrm{MnO}$ & 0.15 & 0.05 & 0.07 & 0.37 & 0.0 & 0.33 & 0.23 & 0.34 & 0.0 & 0.45 & 0.50 & 0.0 \\
\hline $\mathrm{NiO}$ & 0.05 & 0.06 & 0.04 & 0.0 & 0.0 & 0.21 & 0.0 & 0.0 & 0.0 & 0.0 & 0.38 & 0.0 \\
\hline $\mathrm{MgO}$ & 20.15 & 21.82 & 1.04 & 15.04 & 15.05 & 20.11 & 35.54 & 15.84 & 15.34 & 14.97 & 7.36 & 2.54 \\
\hline $\mathrm{CaO}$ & 6.48 & 0.06 & 1.04 & 10.49 & 19.38 & 17.66 & 0.67 & 6.99 & 21.18 & 0.0 & 0.18 & 0.0 \\
\hline $\mathrm{Na}_{2} \mathrm{O}$ & 5.21 & 0.58 & 0.29 & & & & & & & & & \\
\hline $\mathrm{K}_{2} \mathrm{O}$ & 0.86 & 10.22 & 0.75 & & & & & & & & & \\
\hline $\mathrm{BaO}$ & 0.0 & 0.36 & 0.02 & & & & & & & & & \\
\hline $\mathrm{Cl}$ & 0.08 & 0.0 & 0.02 & & & & & & & & & \\
\hline $\mathrm{F}$ & 0.24 & 0.29 & 0.0 & & & & & & & & & \\
\hline Sum & 95.55 & 96.37 & 94.22 & 100.0 & 100.0 & 100.0 & 100.0 & 100.0 & 100.0 & 100.0 & 100.0 & 100.0 \\
\hline
\end{tabular}

1) matrix richterite; 2) matrix mica; 3 ) avg glass ( $n=4)$; 4) garnet and 5) cpx from corundum eclogite; 6) cpx megacryst; 7) opx megacryst; 8) garnet and 9) cpx from bimineralic eclogite; 10) Al-chromite; 11) chromite; 12) pseudobrookite. 1-3 by WDS, 4-12 by EDS. 